\title{
Peningkatan Kompetensi Pedagogik dalam Melaksanakan Melaksanakan Blended Learning pada Guru SDN 1 Tugu Mlarak Ponorogo
}

\author{
Sutrisni $\bowtie$, Universitas PGRI Madiun \\ Sudarmiani, Universitas PGRI Madiun \\ Nurhaji Nugraha, Universitas PGRI Madiun \\ treesniandy@gmail.com
}

\begin{abstract}
This study aims to determine the improvement of pedagogic competence in implementing blended learning in social studies through collaborative educational supervision periodically for SDN 1 Tugu teachers, Mlarak District, Ponorogo Regency. The research method used is a qualitative descriptive. This type of research is a participant School Action Research (PTS). The subjects of this study were teachers from grades 1 to 6 at SDN 1 Tugu. Data collection techniques in this research were using observation, interviews and documentation. The validity of the data was using data reduction, data display and conclusion drawing. Individually, teachers are declared capable if they get monitoring results 71-85 and are declared very capable if they get monitoring results of 86-100. While classical completeness of pedagogical competence in implementing multiple social studies blended learning in the pre-cycle of six teachers there were no teachers with complete criteria (0\%), in cycle 1 there were two teachers who had completed criteria and four teachers had not yet completed (33\%), and in cycle 12 all teachers are complete (100\%). The results of monitoring and evaluation of offline, online, limited face-toface learning and pedagogic observations in cycle 2 are already above the score/monitoring result of 80 so that this research is sufficient for two cycles.
\end{abstract}

Keywords: Pedagogic Competence, Blended Learning, Social Studies, Collaborative Educational Supervision

Abstrak: Penelitian ini bertujuan untuk mengetahui peningkatan kompetensi pedagogik dalam melaksanakan blended learning mupel IPS melalui supervisi edukatif kolaboratif secara periodik guru SDN 1 Tugu Kecamatan Mlarak Kabupaten Ponorogo. Metode penelitian yang digunakan adalah pendekatan deskriptif kualitatif. Jenis peneltian ini adalah Penelitian Tindakan Sekolah (PTS) partisipan. Subyek peneltian ini adalah guru kelas 1 sampai dengan kelas 6 di SDN 1 Tugu. Teknik pengupulan data pada peneltian ini menggunakan observasi, wawancara dan dokumentasi. Validitas data menggunakan menggunakan reduksi data, data display dan conclusion drawing. Secara individu guru dinyatakan mampu apabila memperoleh hasil monitoring 71-85 dan dinyatakan sangat mampu apabila mendapatkan hasil monitoring sebesar 86-100. Sedangkankan ketuntasan secara klasikal kompetensi pedagogik dalam melaksanakan blended learning mupel IPS pada pra siklus dari enam guru tidak ada guru dengan kriteria tuntas ( $0 \%)$, pada siklus 1 ada dua guru kriteria tuntas dan empat guru belum tuntas (33\%), dan pada siklus 2 semua guru tuntas (100\%). Hasil monitoring dan evaluasi pembelajaran luring, daring, tatap muka terbatas dan pengamatan pedagogik pada siklus 2 sudah di atas skor/ hasil monitoring $\geq 80$ sehingga penelitian ini cukup sampai dua siklus.

Kata kunci: Kompetensi Pedagogik, Blended Learning, IPS, Supervisi Edukatif Kolaboratif

Citation: Sutrisni, S., Sudarmiani, S., \& Nugraha, N. (2022). Peningkatan Kompetensi Pedagogik dalam Melaksanakan Melaksanakan Blended Learning pada Guru SDN 1 Tugu Mlarak Ponorogo. Wewarah: Jurnal Pendidikan Multidisipliner, 1(1), 97 - 105. 


\section{PENDAHULUAN}

Pendidikan merupakan usaha untuk mengembangkan potensi sumber daya manusia yang terdiri dari pemberdayaan potensi kognitif, afektif dan psikomotorik. Semua aspek tersebut dibina dan dibimbing melalui berbagai kegiatan belajar mengajar yang biasaanya di selenggarakan pada jenjang pendidikan dari tingkat sekolah dasar, menengah sampai perguruan tinggi. Hal itu sesuai Undang-Undang No.20 Tahun 2003 tentang Sistem Pendidikan Nasional pasal 3 yaitu Pendidikan Nasional berfungsi mengembangkan kemampuan dan membentuk watak serta peradaban bangsa yang bermartabat dalam mencerdaskan kehidupan berbangsa, bertujuan untuk bertaqwa kepada Tuhan Yang Maha Esa, berakhlak mulia, sehat, berilmu, cakap, kreatif, mandiri, dan menjadi warga negara yang demokratis serta bertanggung jawab. (UU No.20 Tahun 2003).

Guru sebagai seorang pendidik memiliki empat kompetensi, salah satunya yaitu kompetensi pedagogik. Kompetensi pedagogik merupakan kemampuan guru dalam pengelolaan pembelajaran peserta didik. Kompetensi Pedagogik merupakan salah satu jenis kompetensi yang mutlak perlu dikuasai guru. Dalam hubungannya dengan kompetensi pedagogik, masih banyak guru yang belum memiliki keterampilan dalam mengelola pembelajaran dengan baik, mulai dari mendesain kegiatan pembelajaran, mengelola pembelajaran, hingga melakukan evaluasi dan perbaikan terhadap pembelajaran yang dilaksanakan terutama yang sesuai dengan perkembangan pendidikan abad 21. Perkembangan dunia abad 21 ditandai dengan pemanfaatan teknologi informasi dan komunikasi dalam segala aspek kehidupan, termasuk dalam proses pembelajaran di sekolah. Sekolah dituntut mampu menyiapkan siswa memasuki abad 21. Hal tersebut melahirkan pembelajaran campuran yaitu pembelajaran tatap muka dan pembelajaran secara online yang disebut dengan blended learning.

WHO (World Health Organization atau Badan Kesehatan Dunia) secara resmi mendeklarasikan virus corona (Covid-19) sebagai pandemi pada tanggal 9 Maret 2021. Artinya, virus corona telah menyebar secara luas di dunia. (covid19.go.id). Penyebaran pandemi virus corona atau Covid-19 telah memberikan tantangan tersendiri bagi lembaga pendidikan di Indonesia. Untuk mengantisipasi penularan virus tersebut pemerintah mengeluarkan kebijakan seperti social distancing, physical distancing, hingga pembatasan sosial berskala besar (PSBB). Hal ini diatur dalam UU No. 6 Tahun 2018 tentang Kekarantinaan Kesehatan yang kemudian dipertegas dengan PP No. 21 Tahun 2020 dan Permenkes 9 tahun 2020 tentang Pembatasan Sosial Berskala Besar (PSBB) pasal 1 yang menyebutkan bahwa Pembatasan Sosial Berskala Besar merupakan pembatasan kegiatan tertentu penduduk dalam suatu wilayah yang diduga terinfeksi Corona Virus Disease 2019 (Covid-19) sedemikian rupa untuk mencegah kemungkinan penyebaran Covid-19.

Akibat dari kebijakan pemerintah pada masa pandemi covid-19 membuat sektor pendidikan seperti sekolah menghentikan proses pembelajaran secara tatap muka. Pembelajaran tatap muka diperbolehkan dengan memenuhi syarat-syarat yang ditentukan pemerintah. Dengan keadaan demikian maka pendidik harus mampu menguasai dan mengaplikasikan teknik pembelajaran di masa pandemi covid-19. Ketika pemerintah menyatakan zona merah pada suatu daerah maka pembelajaran berubah menjadi belajar daring (dalam jaringan dan luring (luar jaringan). Pembelajaran daring memanfaatkan jaringan online yang membutuhkan ketrampilan penggunaan teknologi informatika. Sedangkan pembelajaran luring merupakan model pembelajaran yang dilakukan di luar jaringan bisa berupa pembelajaran tatap muka maupun kunjung kerumah (home visit) Dalam artian, pembelajaran yang satu ini dilakukan secara tatap muka dengan memperhatikan zonasi dan protokol kesehatan yang berlaku.

Guru harus mampu memahami makna dan karakter kurikurikulum terutama kurikulum saat ini yang disederhanakan karena masa darurat. Guru harus menguasai materi, metode, teknik, serta evaluasi pembelajaran sehingga hasil pembelajaran pada suatu satuan pendidikan dapat dicapai secara maksimal dan bermutu. Permendikbud No. 22 Tahun 2016 Pasal 1 menyatakan bahwa Standar Proses Pendidikan Dasar dan Menengah selanjutnya disebut Standar Proses merupakan kriteria mengenai pelaksanaan pembelajaran pada satuan pendidikan dasar dan satuan pendidikan dasar menengah untuk mencapai kompetensi lulusan. (Permendikbud No. 22 Tahun 2016). Dalam pembelajaran, seorang guru sebagai pendidik dituntut untuk mampu mengartikan dan menterjemahkan nilai-nilai dan kompetensi yang terdapat di dalam kurikulum secara optimal. Pada era pembelajaran digital masa pandemi Covid-19 saat ini, seorang guru harus memiliki kemampuan yang memadai baik di bidang akademik maupun pedagogik dengan memanfaatkan teknologi yang berkembang untuk mendesain pembelajaran yang kreatif yang mendorong siswa untuk aktif dan dapat berpikir kreatif. Untuk mencapai kompetensi 
tersebut, seorang guru dituntut harus selalu berinovasi dan meningkatkan kemampuannya baik secara akademik maupun pedagogik dan guru harus meningkatakan kemampuan blended learning secara optimal.

Dari kebijakan pembelajaran pada masa pandemi Covid 19 peneliti melihat hasil belajar khususnya mupel IPS dan mupel-mupel lain pada umumnya yang dicapai siswa di SDN 1 Tugu Kecamatan Mlarak Kabupaten Ponorogo kurang maksimal karena motivasi dan keaktifan belajar siswa tidak sama seperti pembelajaran tatap muka di sekolah, Adapun faktor yang mengakibatkan hasil, motivasi dan keaktifan belajar siswa lebih rendah pada pembelajaran daring antara lain yaitu: 1) tidak semua peserta didik memiliki fasilitas pembelajaran yang menunjang untuk dapat mengakses pembelajaran secara daring, 2) belum adanya kesedaran dari orangtua siswa terkait pentingnya pembelajaran daring, 5) guru kurang mampu dalam berinovasi, memanfaatkan bermacam digital tools, menyelenggarakan kelas online, penerapan kurikulum yang memperkuat model multidisiplin dan kolaboratif dalam belajar mengajar.

Adanya faktor kendala yang menghambat pembelajaran daring tersebut juga telah dipaparkan dalam hasil penelitian Sudarmiani et al (2021) yang menjelaslan bahwa Permasalahan pembelajaran di masa pandemi Covid 19 juga tentu muncul dimulai dari guru yang mengawali proses pembelajaran secara daring seperti dalam hal kurangnya kreativitas dalam penyampaian materi oleh guru dikarenakan hanya mampu menyampaikan materi melalui grup whatsapp, yang selanjutnya akan berdampak pada tingkat pemahaman siswa, Proses tersebut tentunya tidak semudah yang dibayangkan karena dalam prosesnya timbulnya ketidakpahaman atau salah persepsi pada suatu materi sangat mungkin terjadi, belum lagi tugas yang diberikan guru dengan tujuan mengisi kekosongan waktu siswa di rumah yang terlalu banyak sehingga dapat menjadi beban bagi siswa.

Salah satu upaya untuk memenuhi kebutuhan belajar siswa pada kondisi pandemi saat ini yaitu dengan membuat perencanaan pembelajaran yang mengkombinasikan pembelajaran secara daring dan luring (home visit dan tatap muka terbatas) dengan merancang model pembelajaran yang bisa diterapkan saat ini. Model pembelajaran perlu dirancang dan dikembangkan sedemikian rupa untuk mendukung jalannya proses belajar mengajar dengan baik (Darmawan dan Wahyudin, 2018:1). Model pembelajaran memilki peran yang besar terhadap prestasi maupun motivasi belajar siswa terlebih lagi pada masa pandemi Covid-19 saat ini. Guru harus pandai memodifikasi pembelajaran dengan model yang inovatif dan kreatif..

Model pembelajaran yang dapat dilakukan pada kondisi saat ini salah satunya adalah model pembelajaran kombinasi atau yang dikenal dengan istilah blended learning. Munir (2017:63) mengungkapkan bahwa blended learning adalah pembelajaran yang mengkombinasikan strategi penyampaian pembelajaran menggunakan kegiatan tatap muka, pembelajaran berbasis komputer secara offline, dan komputer secara online (internet dan mobile learning). Blended learning ini bukan hanya sebagai model pembelajaran yang inovatif dalam mengkombinasikan pelaksanaan pembelajaran. Namun juga sebagai inovasi untuk mengenalkan kemajuan teknologi dalam bidang pendidikan melalui model pembelajaran. Dwiyanto (2020:4) juga mengatakan bahwa blended learning sebagai solusi menjawab tantangan dalam merangkai pembelajaran dan pengembangan individu peserta didik. Menurut Dwiyogo (2018:60) melalui blended learning semua sumber belajar dapat memfasilitasi terjadinya proses belajar bagi orang yang belajar dikembangkan Sehingga blended learning sangat tepat digunakan pada situasi saat ini. Dalam hal ini peneliti memandang bahwa blended learning cocok diterapkan guru dalam pembelajaran di masa pandemic saat ini. Selain itu blended learning sejalan dengan pembelajaran abad ke-21 yang cepat sekali mengalami pergeseran atau perubahan.

Pembelajaran dapat terlaksana dengan baik apabila terdapat interkasi antar peserta didik, guru dan kepala sekolah. Kondisi pembelajaran yang sangat efektif, efisien, menyenangkan dan menarik minat belajar siswa sangat diperlukan pada kondisi pandemi Covid-19 saat ini. Guru harus memiliki kompetensi pedagogik yang memadahi dalam melaksanakan blended learning. Dengan kata lain guru harus berinovasi, mampu memanfaatkan bermacam digital tools, menyelenggarakan kelas online maupun offline. Desain pembelajaran dan kinerja guru dipengaruhi oleh kepemimpinan dan kinerja kepala sekolah. Pada masa pandemi ini, kepala sekolah dan guru merumuskan ulang metode, media dan penilaian yang akan diterapkan. Kepala sekolah dalam melaksanakan perannya sebagai supervisor harus 
selalu memantau dan mengawasi keberlangsungan kegiatan pembelajaran serta diuntut untuk dapat menjadi teladan atau role model untuk seluruh anggota sekolah lainnya seperti guru.

Ada beberapa penelitian sebelumnya tentang penerapan blended learning dan supervisi edukatif kolaboratif secara periodik untuk mengatasi masalah kemampuan guru dalalm berinovasi pada pembelajaran. Penelitian yang dilakukan oleh Zakiyah Mawadah (2021) dengan judul Implementasi Model Pembelajaran Blended Learning Di Kelas V Sekolah Dasar Pada Masa Pandemi Covid-19 di SD Negeri 551 Kecamatan Muara Bulian Kabupaten Batang Hari Propinsi Jambi dapat meningkatkan hasil pembelajaran siswa. Tesis hasil penelitian Riella Anggun Hidayati (2020) yang berjudul Pengembangan Media Pembelajaran E-Learning Berbasis Web Melalui Blended Learning Pada Mata Pelajaran Sejarah Kebudayaan Islam Dalam Meningkatkan Hasil Belajar Siswa Di Madrasah Tsanawiyah Nusantara Kota Probolinggo, menunjukkan hasil tingkat keefektifan pada media pembelajaran e-learning berbasis website melalui blended learning dapat dilihat nilai pre-test post-test yang hasilnya terbukti efektif. Penelitian yang berjudul Analisis Kompetensi Pedagogik Guru Dalam Pengelolaan Proses Pembelajaran Pada Masa Pandemi Covid-19 Di SDN Jatimulyo 1 karya Retno Handini Palasari (2021) menunjukkan hasil bahwa setiap guru kelas telah menguasai kompetensi pedagogik guru, hal ini ditunjukkan dengan penguasaan guru terhadap indikator kompetensi pedagogik masing-masing guru. Selanjutnya penelitian Wahyudiono Jokomarsono (2019) dengan judul Supervisi Edukatif Kolaboratif secara Periodik sebagai Upaya Peningkatan Kinerja Guru Dalam Pembelajaran di SMK Negeri 1 Kademangan Kabupaten Blitar Jawa Timur dapat meningkatkan kinerja guru dalam pembelajaran.

Untuk meningkatkan kemampuan pedagogik guru, peneliti yang sekaligus kepala sekolah di SDN 1 Tugu Kecamatan Mlarak Kabupaten Ponorogo, melakukan kegiatan supervisi pembelajaran secara periodik bukan hanya untuk penilaian kinerja guru dalam mengelola proses pembelajaran di kelas tetapi juga menilai keberhasilan peserta didik dalam pembelajaran terutama di masa pandemi Covid-19, sehingga kepala sekolah dapat berperan sebagai educator, manager, supervisor, leader, innovator, dan motivator yang memilik kemampuan kepribadian, manajerial, kewirausahaan, supervisi dan sosial.

\section{METODE PENELITIAN}

Pendekatan penelitian dalam Penelitian Tindakan Sekolah (PTS) ini menggunakan pendekatan deskriptif kualitatif sebab dengan pendekatan kualitatif peneliti dapat menguraikan data yang diperoleh. Moleong (2015:6) mengatakan penelitian deskriptif kualitatif meurpakan penelitian yang bersifat menggambarkan, menguraikan suatu hal sesuai apa adanya Menurut Arikunto dkk., (2008:56-57) pendekatan diawali dengan memaparkan (mendeskripsikan) informasi tentang suatu gejala atau peristiwa, dan kejadian apa adanya kemudian ditindaklanjuti dengan eksperimen dengan mengumpulkan informasi atau data mengenai akibat dari adanya perlakuan (treatment)".

Jenis penelitian ini adalah Penelitian Tindakan Sekolah (PTS) atau disebut School Action Research. Penelitian Tindakan Sekolah (PTS) merupakan penelitian tindakan untuk memecahkan masalah proses pembelajaran di tingkat sekolah dan biasanya dilaksanakan oleh peneliti yang umumnya praktisi di sekolah tersebut. Menurut Asrori (2008:48) peneliti harus terlibat secara penuh dalam keseluruhan rangkaian penelitian diawali dari penemuan masalah, perumusan masalah, perumusan rencana tindakan, pelaksanaan tindakan, observasi tindakan, melakukan refleksi, analisis dan pemaknaan hasilnya serta penarikan kesimpulan.

Penulis melakukan observasi secara langsung melalui supervisi edukatif kolaboratif pada pelaksanaan blended learning muatan pelajaran IPS yang dilakukan para guru di SDN 1 Tugu Kecamatan Mlarak Kabupaten Ponorogo. Peneliti menggunakan model kolaboratif dengan melibatkan semua guru. Subyek peneltian ini adalah guru kelas 1 sampai dengan kelas 6 SDN 1 Tugu Kecamatan Mlarak Kabupaten Ponorogo.

Teknik pengumpulan data yang digunakan dalam penelitian ini adalah 1) Observasi. Metode observasi adalah suatu cara mendapatkan atau mengumpulkan data yang dilakukan dengan jalan mengadakan pengamatan dan pencatatan secara sistematis tentang suatu objek tertentu. (Suharsimi Arikunto,2010:68). Pada penelitian ini, observasi dilakukan pada saat guru-guru melakukan pembelajaran selama pandemi Covid-19 yang menggunakan blended learning. 2) Wawancara. Teknik wawancara untuk memantau dan menggali data yang hanya bisa diungkapkan dengan kata-kata secara 
lisan oleh sumbernya". (Asrori 2010:110). Peneliti melakukan wawancara terhadap guru-guru di SDN 1 Tugu Kecamatan Mlarak Kabupaten Ponorogo tentang pelaksanaan pembelajaran selama pandemi Covid-19 yang pembelajaranya menggunakan pembelajaran campuran (blended learning) 3) Dokumentasi merupakan informasi yang penting bagi peneliti. Dokumen yang dimaksudkan adalah semua catatan harian guru, kepala sekolah, dokumen supervisi, dokumentasi foto, video yang berhubungan dengan penelitian

Untuk memecahkan masalah penelitian yang telah disampaikan di depan, maka dilakukan langkah-langkah dalam penelitian tindakan sekolah yang terdiri dari perencanaan, pelaksanaan tindakan, observasi, dan evaluasi-refleksi yang bersifat daur ulang atau siklus. Metode yang digunakan dalam penelitian ini adalah metode deskriptif, dengan menggunakan teknik persentase untuk melihat peningkatan yang terjadi dari siklus ke siklus. Siklus akan terus dilakukan atau berlanjut apabila permasalahan belum terselesaikan. Dengan metode ini peneliti berupaya menjelaskan data yang dikumpulkan melalui komunikasi langsung atau wawancara, observasi/pengamatan, dan diskusi yang berupa persentase atau angka-angka. Prosedur penelitian ini terdiri dari 4 tahap kegiatan yaitu (1) Tahap penyusunan rencana tindakan; (2) Tahap pelaksanaan tindakan; (3) Tahap Pengamatan atau observasi; dan (4) Tahap perefleksian.

Analisis data yang dipergunakan dalam penelitian ini adalah analisis data statistik deskriptif dan analisis kualitatif model interaktif. Analisis data statistik deskriptif dilakukan dengan cara menghitung data hasil kemampuan guru dalam melaksanakan blended learning dari hasil observasi dan dokumentasi. Sedangkan analisis kualitatif model interaktif digunakan untuk menganalisis hasil wawancara. Adapun tahapannya adalah 1) Reduksi Data. Reduksi data dilakukan dengan memfokuskan sekaligus memilahmilah data supervisi pembelajaran peningkatan kinerja guru baik dalam kompetensi pedagogik. Setelah dilakukan belajar bersama dalam bentuk In House Training dan penerapannya pada proses pembelajaran dalam melaksanakan blended learning, penyajian data dilakukan dengan cara memaparkan secara naratif hasil reduksi data. Penarikan simpulan dilakukan dengan cara menemukan rasionalisasi dan justifikasi hasil tindakan berdasarkan reduksi data dan penyajian data yang telah dirumuskan.. 2) Data Display. Data yang sudah ada perlu disajikan, karena data merupakan informasi yang dapat dipergunakan untuk menarik suatu kesimpulan, dan dapat dipergunakan untuk mengambil tindakan selanjutnya. Informasi yang diperoleh dapat berupa informasi yang berbentuk teks naratif, dan teks naratif ini perlu diadakan penyederhanaan sehingga diperoleh bentuk yang sederhana yang mudah dipahami. 3) Conclusion Drawing atau Menarik Kesimpulan dan Verifikasi Data. Kesimpulan dalam penelitian ini ditarik dari catatan-catatan yang diperoleh dari catatan lapangan, pengkodean, penyimpanan dan merupakan sebagian dari adanya kegiatan dalam penelitian. Kesimpulan ini perlu ditelaah kembali atau diverifikasi untuk mencari pembuktian yang berikutnya.

Kaitannya dengan analisis data kualitatif tersebut, diperoleh berdasarkan hasil observasi lapangan, wawancara, catatan lapangan. Hasil observasi lapangan diperoleh dari aktivitas dalam belajar bersama dalam bentuk in house training dan proses pembelajaran serta aktivitas guru. Data kualitatif dipaparkan dalam kalimat yang dipisahkan menurut kategori untuk memperoleh kesimpulan.

\section{HASIL PENELITIAN}

Hasil monitoring dan evaluasi akhir rata-rata secara klasikal Siklus 1 yang terdiri hasil monitoring pembelajaran luring home visit $(\mathrm{H} 1)$, hasil monitoring pembelajaran luring tatap muka terbatas $(\mathrm{H} 2)$, hasil monitoring pembelajaran daring (H3) dan hasil monitoring kompetensi pedagogik (H4) kemudian diolah untuk menentukan hasil akhir monitoring dan evaluasi secara individu dan klasikal pelaksanaan blended learning (HA) dan ketuntasan klasikal Siklus 1 dengan rumus seperti berikut:

$$
\mathrm{HA}=\frac{\mathrm{H} 1+\mathrm{H} 2+\mathrm{H} 3+\mathrm{H} 4}{5}
$$


Tabel 1 Rekapitulasi Hasil Monitoring Evaluasi/ Supervisi Pelaksanaan Blended Learning Siklus 1 Hasil monitoring evaluasi akhir rata-rata secara klasikal Siklus 2 yang terdiri hasil monitoring

\begin{tabular}{|c|c|c|c|c|c|c|c|c|c|}
\hline No & $\begin{array}{c}\text { Nama } \\
\text { Guru }\end{array}$ & $\begin{array}{c}\text { Guru } \\
\text { Kelas }\end{array}$ & H1 & H2 & H3 & H4 & JML & HA & Ketuntasan \\
\hline 1 & A & 1 & 82 & 81 & 86 & 78 & 327 & 82 & Mampu/Tuntas \\
\hline 2 & B & 2 & 68 & 71 & 71 & 70 & 280 & 70 & Mampu/Belum Tuntas \\
\hline 3 & C & 3 & 79 & 71 & 77 & 75 & 302 & 76 & Mampu/Belum Tuntas \\
\hline 4 & D & 4 & 79 & 73 & 77 & 75 & 304 & 76 & Mampu/Belum Tuntas \\
\hline 5 & E & 5 & 68 & 69 & 71 & 68 & 276 & 69 & Mampu/Belum Tuntas \\
\hline 6 & F & 6 & 82 & 79 & 86 & 78 & 325 & 81 & Mampu/Tuntas \\
\hline & \multicolumn{2}{|c|}{ Rata-Rata Hasil } & 76 & 74 & 78 & 74 & 302 & 76 & \\
\hline
\end{tabular}

evaluasi pembelajaran luring home visit (H1), hasil monitoring pembelajaran luring tatap muka terbatas $(\mathrm{H} 2)$, hasil monitoring pembelajaran daring $(\mathrm{H} 3)$ dan hasil monitoring kompetensi pedagogik $(\mathrm{H} 4)$ pada guru SDN 1 Tugu di atas kemudian diolah untuk menentukan hasil akhir monitoring secara klasikal pelaksanaan blended learning (HA) dan ketuntasan klasikal Siklus 2 dengan rumus seperti berikut:

$\mathrm{HA}=\frac{\mathrm{H} 1+\mathrm{H} 2+\mathrm{H} 3+\mathrm{H} 4}{5}$

Adapun hasilnya sebagaimana tercantum dalam table di bawah ini:

Tabel 2 Rekapitulasi Hasil Monitoring Pelaksanaan Blended Learning Siklus 2

\begin{tabular}{|c|c|c|c|c|c|c|c|c|c|}
\hline No & $\begin{array}{c}\text { Nama } \\
\text { Guru }\end{array}$ & $\begin{array}{l}\text { Guru } \\
\text { Kelas }\end{array}$ & H1 & $\mathrm{H} 2$ & $\mathrm{H} 3$ & $\mathrm{H} 4$ & JML & HA & Individu/klasikal \\
\hline 1 & A & 1 & 89 & 88 & 88 & 88 & 353 & 88 & Sangat mampu/tuntas \\
\hline 2 & B & 2 & 86 & 79 & 81 & 83 & 329 & 82 & Mampu /Tuntas \\
\hline 3 & $\mathrm{C}$ & 3 & 86 & 82 & 79 & 85 & 332 & 83 & Mampu/ Tuntas \\
\hline 4 & $\mathrm{D}$ & 4 & 86 & 82 & 83 & 85 & 336 & 84 & Mampu /Tuntas \\
\hline 5 & $\mathrm{E}$ & 5 & 82 & 79 & 75 & 85 & 321 & 80 & Mampu /Tuntas \\
\hline 6 & $\mathrm{~F}$ & 6 & 93 & 89 & 88 & 88 & 358 & 90 & Sangat mampu/tuntas \\
\hline \multicolumn{3}{|c|}{ Rata-Rata Hasil } & 87 & 83 & 82 & 86 & 338 & 85 & \\
\hline
\end{tabular}

\section{PEMBAHASAN}

Tolak ukur keberhasilan penelitian tindakan sekolah ini yang dilakukan dua siklus terlihat dari dua sisi, yaitu sisi proses dan sisi hasil. Dari sisi proses ada peningkatan guru dalam melaksanakan blended learning di masa pandemi covid 19 ini baik secara klasikal maupun individu. Secara individu guru dinyatakan mampu apabila memperoleh hasil monitoring 71-85 dan dinyatakan sangat mampu apabila mendapatkan hasil monitoring sebesar 86-100. Sedangkan secara klasikal guru dinyatakan tuntas atau berhasil jika mampu melaksanakan blended learnimg secara benar dan bervariasi mencapai hasil $\geq 80$.

Berikut ini adalah keadaan kemampuan secara individu kompetensi pedagogik guru dalam pelaksanaan blended learning mupel IPS: 
Tabel 3 Rekapitulasi Capaian Ketuntasan Hasil Supervisi Pelaksanaan Blended Learning Mupel IPS Secara Indivdu

\begin{tabular}{|c|c|c|c|c|c|c|c|c|c|c|c|c|c|}
\hline \multirow[t]{2}{*}{ No } & \multirow[t]{2}{*}{$\begin{array}{c}\text { Nama } \\
\text { guru }\end{array}$} & \multirow[t]{2}{*}{$\begin{array}{l}\text { Guru } \\
\text { Kelas }\end{array}$} & \multicolumn{3}{|c|}{$\begin{array}{c}\text { Pembelajaran Luring } \\
\text { Home Visit }\end{array}$} & \multicolumn{3}{|c|}{$\begin{array}{c}\text { Pembelajaran Luring } \\
\text { Tatap Muka } \\
\text { Terbatas }\end{array}$} & \multicolumn{3}{|c|}{$\begin{array}{l}\text { Pembelajaran } \\
\text { Daring }\end{array}$} & \multicolumn{2}{|c|}{$\begin{array}{c}\text { Aspek } \\
\text { Pedagogik }\end{array}$} \\
\hline & & & PS & S1 & S2 & PS & S1 & S2 & PS & S1 & S2 & $\mathrm{S} 1$ & S2 \\
\hline 1 & $\mathrm{~A}$ & 1 & 75 & 82 & 89 & 80 & 86 & 88 & 75 & 81 & 88 & 78 & 88 \\
\hline 2 & B & 2 & 64 & 68 & 86 & 68 & 71 & 79 & 67 & 71 & 81 & 70 & 83 \\
\hline 3 & $\mathrm{C}$ & 3 & 68 & 79 & 86 & 75 & 77 & 82 & 67 & 71 & 79 & 75 & 85 \\
\hline 4 & $\mathrm{D}$ & 4 & 68 & 79 & 86 & 73 & 77 & 82 & 71 & 73 & 83 & 75 & 85 \\
\hline 5 & $E$ & 5 & 64 & 68 & 82 & 68 & 71 & 79 & 62 & 69 & 75 & 68 & 85 \\
\hline 6 & $\mathrm{~F}$ & 6 & 75 & 82 & 93 & 84 & 86 & 89 & 73 & 79 & 88 & 78 & 88 \\
\hline \multicolumn{3}{|c|}{ Rata-Rata Hasil } & 69 & 76 & 87 & 75 & 78 & 83 & 69 & 74 & 82 & 74 & 82 \\
\hline
\end{tabular}

PS= Pra Siklus, S1= Siklus 1, S2=Siklus 2

Tabel 4 Rekapitulasi Capaian Ketuntasan Hasil Supervisi Pelaksanaan Blended Learning Mupel IPS Secara Klasikal

\begin{tabular}{|c|c|c|c|c|c|c|c|c|c|c|c|}
\hline \multirow{2}{*}{ No } & \multirow{2}{*}{$\begin{array}{c}\text { Nama } \\
\text { Guru }\end{array}$} & \begin{tabular}{c} 
志 \\
\cline { 4 - 13 }
\end{tabular} & $\begin{array}{c}\text { Skor } \\
\text { Rata- } \\
\text { rata }\end{array}$ & $\begin{array}{c}\text { Batas } \\
\text { Tuntas }\end{array}$ & $\begin{array}{c}\text { Ketun } \\
\text { tasan }\end{array}$ & $\begin{array}{c}\text { Skor } \\
\text { Rata- } \\
\text { rata }\end{array}$ & $\begin{array}{c}\text { Batas } \\
\text { Tuntas }\end{array}$ & $\begin{array}{c}\text { Ketun } \\
\text { tasan }\end{array}$ & $\begin{array}{c}\text { Skor } \\
\text { Rata- } \\
\text { rata }\end{array}$ & $\begin{array}{c}\text { Batas } \\
\text { Tuntas }\end{array}$ & $\begin{array}{c}\text { Ketun } \\
\text { tasan }\end{array}$ \\
\hline 1 & $\mathrm{~A}$ & 1 & 77 & 80 & $\mathrm{BT}$ & 82 & 80 & $\mathrm{~T}$ & 88 & 80 & $\mathrm{~T}$ \\
\hline 2 & $\mathrm{~B}$ & 2 & 66 & 80 & $\mathrm{BT}$ & 70 & 80 & $\mathrm{BT}$ & 82 & 80 & $\mathrm{~T}$ \\
\hline 3 & $\mathrm{C}$ & 3 & 70 & 80 & $\mathrm{BT}$ & 76 & 80 & $\mathrm{BT}$ & 83 & 80 & $\mathrm{~T}$ \\
\hline 4 & $\mathrm{D}$ & 4 & 71 & 80 & $\mathrm{BT}$ & 76 & 80 & $\mathrm{BT}$ & 84 & 80 & $\mathrm{~T}$ \\
\hline 5 & $\mathrm{E}$ & 5 & 65 & 80 & $\mathrm{BT}$ & 69 & 80 & $\mathrm{BT}$ & 80 & 80 & $\mathrm{~T}$ \\
\hline 6 & $\mathrm{~F}$ & 6 & 77 & 80 & $\mathrm{BT}$ & 81 & 80 & $\mathrm{~T}$ & 90 & 80 & $\mathrm{~T}$ \\
\hline \multicolumn{2}{|l|}{ Ketuntasn (\%) } & & & $0 \%$ & & & $33 \%$ & & & $100 \%$ \\
\hline
\end{tabular}

Keterangan $\mathrm{T}=$ Tuntas, $\mathrm{BT}=$ Belum Tuntas

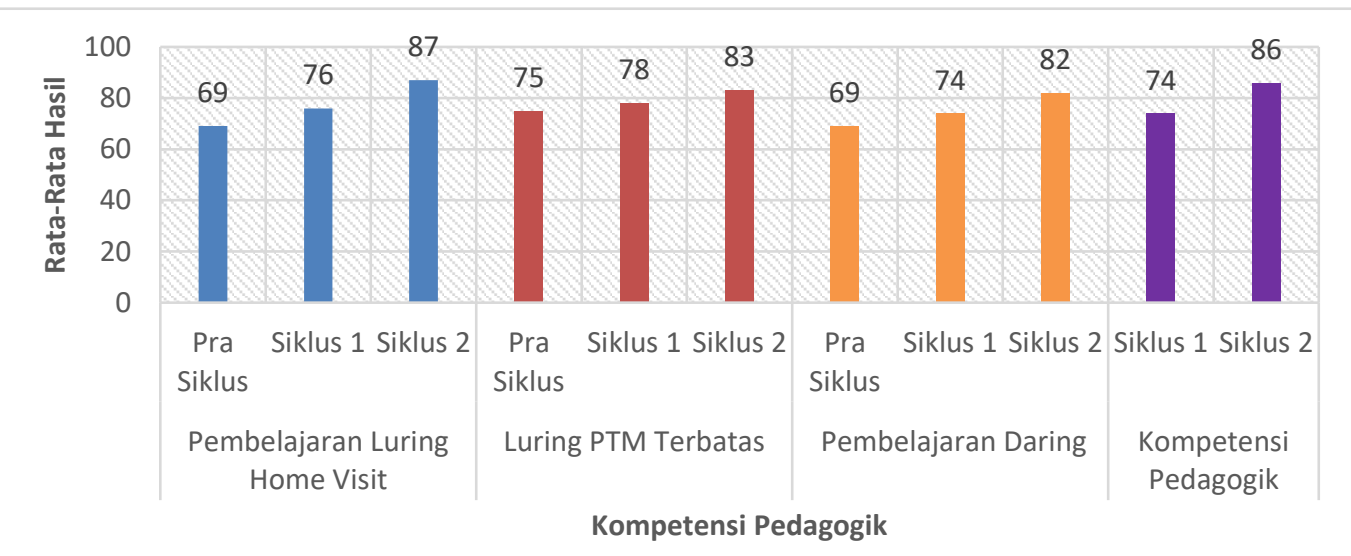

Gambar 1. Rekapitulasi Hasil Supervisi Pelaksanaan Blended Learning Mupel IPS

Berikut ini adalah keadaan kemampuan secara individu kompetensi pedagogik guru dalam pelaksanaan 1) pembelajaran luring home visit mupel IPS yaitu pada Siklus 1 ada empat guru mampu 
dan dua guru cukup dalam melaksanakan pembelajaran luring home visit sedangkan pada Siklus 2 ada lima guru sangat mampu dan satu guru mampu dalam melaksanakan pembelajaran luring home visit 2) Pada pembelajaran luring tatap muka terbatas terlihat pada Siklus 1 ada dua guru sangat mampu dan empat guru mampu melaksanakan pembelajaran tatap muka terbatas sedangkan pada Siklus 2 ada dua guru sangat mampu dan empat guru mampu melaksanakan pembelajaran tatap muka terbatas. 3) Pada pembelajaran daring terlihat pada Siklus 1 ada lima guru mampu dan satu guru cukup dalam melaksanakan pembelajaran daring sedangkan pada Siklus 2 ada dua guru sangat mampu dan empat guru mampu melaksanakan pembelajaran daring. 4) Pada pengamatan aspek pedagogik terlihat kemampuan guru dalam melaksanakan blended learning secara individu dari enam guru yaitu ada lima guru mampu dan satu guru cukup pada pengamatan aspek kompetensi pedagogik pada siklus 1 dan dua guru sangat mampu dan empat guru mampu pada aspek pengamatan kompetensi pedagogik. Ketuntasan secara individu terlihat meningkat pada setiap aspek pembelajaran maupun pengamatan aspek pedagogik dari Pra Siklus ke Siklus 1 dan dari Siklus 1 ke Siklus 2

Sedangkankan ketuntasan secara klasikal kompetensi pedagogik dalam melaksanakan blended learning mupel IPS dari enam guru kelas terlihat pada tabel 4.21 yaitu pada Pra Siklus dari enam guru tidak ada guru dengan kriteria tuntas $(0 \%)$, pada Siklus 1 ada dua guru kriteria tuntas dan empat guru belum tuntas (33\%), dan pada siklus 2 semua guru tuntas (100\%). Hasil supervisi (monitoring dan evaluasi) pembelajaran luring, daring, tatap muka terbatas dan pengamatan pedagogik pada siklus 2 sudah di atas skor/ hasil monitoring $\geq 80$ sehingga penelitian ini cukup sampai dua siklus.

Supervisi edukatif kolaboratif yang dilakukan penelti terhadap enam orang guru kelas di SD Negeri 1 Kecamatan Mlarak Kabupaten Ponorogo berhasil meningkatkan kompetensi pedagogik guru dalam melaksanakan blended learning mupel IPS. Hal tersebut karena adanya kerja sama yang baik anatara peneliti sebagai supervisor dengan para guru sehingga para guru termotivasi untuk meningkatkan kempotensi pedagogic mereka dalam melaksanakan pembelajaran pada umumnya dan blended learning pada khususnya.

\section{SIMPULAN}

Supervisi edukatif kolaboratif dapat meningkatkan kompetensi pedagogik dalam melaksanakan blended learning mupel IPS secara individual dari segi proses. Hal tersebut terlihat adanya peningkatan hasil supervisi (monitoring evaluasi) secara individu dari Pra Siklus ke Siklus 1 dan dari Siklus 1 ke Siklus 2. Skor rata- rata Pra Siklus pembelajaran luring home visit sebesar 69, luring tatap muka terbatas sebesar 75, daring sebesar 69, dengan skor rata-rata kesuluruhan aspek 71, skor rata-rata Siklus 1 pembelajaran luring home visit sebesar 76, tatap muka terbatas 78 , daring sebesar 74, dan pengamatan aspek pedagogik sebesar 74 dengan rata-raa keseluruhan aspek 75,5, dan skor rata-rata pada Siklus 2 pembelajaran luring 87, tatap muka terbatas 83, daring 82, dan aspek pengamatan pedagogik sebesar 86 dengan rata-rata keseluruhan aspek sebesar 84 .

Supervisi edukatif kolaboratif mampu meningkatkan kompetensi pedagogik dalam melaksanakan blended learning mupel IPS secara klasikal di lihat dari segi hasil. Hal tersebut terlihat dari ketuntasan klasikal guru sudah mencapai batas tuntas $\geq 80$. Pada Pra Siklus belum ada guru yang tuntas ( $0 \%)$, pada Siklus 1 ada dua guru melampaui batas tuntas (33\%), dan pada Siklus 2 semua guru mencapai ketuntasan (100\%) Dengan demikian ada peningkatan secara signifikan dari siklus 1 ke Siklus 2 yaitu sebesar 67\%.

\section{DAFTAR PUSTAKA}

Ansori, M. (2018). Desain dan Evaluasi Pembelajaran Blended Learning Berbasis Whatsapp Group (WAG). Dirasah: Jurnal Studi Ilmu dan ManajemenPendidikan Islam, (1), 120-134.

Hidayati, R.A. (2020) Pengembangan Media Pembelajaran E-Learning Berbasis Web Melalui Blended Learning Pada Mata Pelajaran Sejarah Kebudayaan Islam Dalam Meningkatkan Hasil Belajar Siswa. Thesis. (http://etheses.uin-malang.ac.id/22345 Diakses pada tanggal 24 Agustus 2021 pada pukul 16.00 WIB).

Jokomarsono, W. (2019) Supervisi Edukatif Kolaboratif Secara Periodik Sebagai Upaya Peningkatan Kinerja Guru Dalam Pembelajaran. Jurnal Dinamika Manajemen Pendidikan (online) 4(1) 
(https://journal.unesa.ac.id/index.php/jdmp/article/view/5302, diakses pada tanggl 23 Maret 2021 Pukul 16.00 WIB).

Nico, Sudarmiani, Rifai (2021) Analisis Kendala Guru dalam Pembelajaran Daring Mata Pelajaran IPS Pada Masa Pandemi COVID-19: Studi Kasus di Sekolah Menengah Pertama Kota Madiun. Jurnal. Universitas Wiralodra Jawa Barat P-ISSN 1693-7945, E-ISSN: 2622-1969 Gema Wiralodra, Vol 12, No 2, Oktober 2021.

Palasari, R.H. (2021) Analisis Kompetensi Pedagogik Guru Dalam Pengelolaan Proses Pembelajaran Pada Masa Pandemi Covid-19. Thesis. (https://eprints.umm.ac.id/74017/ diakses pada tanggal 24 Agustus 2021 Pada Pukul 16.40 WIB).

Restu, Rahmah, H., Halimah, S. (2019, October). Desain Pembelajaran Berbasis Blended Learning Di Era Revolusi 4.0. Prosiding Seminar Nasional Fakultas Ilmu Sosial Universitas Negeri Medan Vol 3 Tahun 2019, hal $1001-1003$.

Sulvemi, W.B. (2015) Kemampuan Pedagogik Huru. Prosiding Seminar Nasional STKIP Muhammadiyah Bogor VOL. 1 No. 1. ISSN: 9772-443-2701-4.

Arikunto, Suharsimi. (2010). Prosedur Penelitian Suatu Pendekatan Praktik. Jakarta: Rineka Cipta.

Asrori, M (2008) Penelitian Tindakan Kelas. Bandung: Wacana Prima.

Darmawan, D \& Wahyudin, D. (2018). Model Pembelajaran di Sekolah. Bandung: PT Remaja Rosdakarya.

Dwiyanto. 2020. New_Normal_Blended_Learning. http://lpmplampung.kemdikbud.go.id. Akses pada 22 Juli 2021.

Dwiyogo Wasis. (2008). Pembelajaran Berbasis Blended Learning. Depok: Rajawali Pers.

Moleong, Lexy, J. (2015) Metode Penelitian Kualitatif. Bandung: Remaja Rosdakarya.

Munir. (2017). Pembelajaran Digital. Bandung: Alfabeta.

Munir. (2012). Pembelajaran Jarak jauh Berbasis Teknologi Informasi dan Komunikasi. Bandung: Alfabeta.

Peraturan Pemerintah No. 21 Tahun 2020 tentang Pembatasan Sosial Berskala Besar (PSBB) (https://peraturan.bpk.go.id) Diakses pada tanggal 25 Juli 2021.

Permendikbud No. 22 Tahun 2016 tentang Standar Proses (https://bsnp-indonesia.org) diakses pada tanggal 25 Juli 2021. Undang-Undang No.20 Tahun 2003 tentang Sistem Pendidikan Nasional https://covid19.go.id/tanyajawab? Diakses pada tanggal 24 Agustus 2021 pada pukul 16.00 WIB).

Undang-Undang No. 6 Tahun 2018 tentang Kekarantinaan Kesehatan (https://peraturan.bpk.go.id) Diakses pada tanggal 24 Agustus pada pukul 16.25. 